\title{
On the rare Neotropical genus Ophionthus Bernhauer (Coleoptera: Staphylinidae: Staphylininae): redescription of the type species and description of a new species
}

\author{
Maryzender RODRÍGUEZ-MELGAREJO ${ }^{1, *} \&$ Mariana CHANI-POSSE ${ }^{2}$ \\ ${ }^{1,2}$ Laboratorio de Entomología, Instituto Argentino de Investigaciones de las Zonas Áridas \\ (IADIZA, CCT CONICET, Mendoza), Casilla de Correo 507, 5500 Mendoza, Argentina. \\ ${ }^{1}$ Departamento de Entomología, Museo de Historia Natural, Universidad Nacional Mayor \\ de San Marcos, Apartado 14-0434, Lima 14, Perú. \\ ${ }^{2}$ Facultad de Ciencias Exactas y Naturales, Universidad Nacional de Cuyo, Mendoza, Argentina. \\ *Corresponding author: maryzender@gmail.com \\ 2Email: mchani@mendoza-conicet.gob.ar \\ ${ }^{1}$ urn:Isid:zoobank.org:author:87008917-24CD-4AB6-93A2-D43661331FD3 \\ ${ }^{2}$ urn:1sid:zoobank.org:author:2A1940FC-287E-45D1-9357-32C4ACB34C6F \\ ${ }^{1} \odot \mathrm{https}^{2} / /$ orcid.org/0000-0002-3516-4270
${ }^{2} \odot \mathrm{https}: / /$ orcid.org/0000-0002-3466-7669
}

\begin{abstract}
Two female specimens of the Neotropical genus Ophionthus Bernhauer were found during museum collection surveys, representing different species of the genus. These species are Ophionthus serpentinus Bernhauer, 1908 and $O$. asenjoi sp. nov. The genus Ophionthus was monotypic until the present study and only known from a single male specimen from Central Peru. The genus is redescribed with the inclusion of female characters from both the type species and the new species here proposed. Additionally, the systematic position of Ophionthus within the Neotropical lineage of Philonthina and its geographical distribution in Peru are reassessed. Descriptions, diagnoses, illustrations, pictures, a cladogram, and a distribution map are provided.
\end{abstract}

Keywords. Neotropical Philonthina, Jelski, Weyrauch, type locality, Ophionthus asenjoi sp. nov.

Rodríguez-Melgarejo M. \& Chani-Posse M. 2021. On the rare Neotropical genus Ophionthus Bernhauer (Coleoptera: Staphylinidae: Staphylininae): redescription of the type species and description of a new species. European Journal of Taxonomy 735: 15-33. https://doi.org/10.5852/ejt.2021.735.1237

\section{Introduction}

Philonthina Kirby, 1837 is the most speciose subtribe inside the mega-diverse rove beetle tribe Staphylinini Latreille, 1802 (Chani-Posse et al. 2018a), accounting for more than 2800 species classified in 75 genera worldwide. Thirty-five of these occur in Central and South America (CASA) (including Mexico and all other countries of Central and South America) and 24 are endemic to CASA (Chani- 
Posse et al. 2018b; Asenjo et al. 2019; Chani-Posse \& Ramírez-Salamanca 2020a, 2020b; RamírezSalamanca et al. 2020).

One of these genera that is endemic to CASA is Ophionthus, that was described by Bernhauer (1908) to accommodate the species Ophionthus serpentinus Bernhauer, 1908 which was fixed as the type species by subsequent monotypy (Blackwelder 1952). Since then, references to this genus in the literature have been scarce and mostly limited to citations in catalogues and checklists (e.g., Blackwelder 1944; Herman 2001), until recent studies placed it within the Neotropical lineage of Philonthina and nested within the so-called Paederomimus-complex (e.g., Chani-Posse 2013; Chani-Posse et al. 2018a, 2018b; ChaniPosse \& Ramírez-Salamanca 2020a, 2020b). However, the most recent results (Chani-Posse \& RamírezSalamanca 2020a) cast doubt on its current status due to its placement within a group of species closely related to Musicoderus Sharp, 1885 and the presence of protarsomeres with discal setae on their ventral surface, also found in other Neotropical genera (Chani-Posse \& Ramírez-Salamanca 2020b; RamírezSalamanca et al. 2020). Therefore, a reassessment of its morphological characters as well as further insights into its biogeographical affinities are needed to clarify its generic limits and phylogenetic relationships within the Neotropical Philonthina lineage (Chani-Posse \& Ramírez-Salamanca 2020a, 2020b).

Since its original description, Ophionthus serpentinus has only been known from a unique specimen, the male holotype collected by Jelski in 1873 from "Peruvia centralis", with no further data on the label (Bernhauer 1908; Chani-Posse et al. 2018b). Konstanty Roman Jelski (1837-1896) was a Polish naturalist who carried out field collections in northern and central Peru between 1869 and 1879 (Lamas 1980; Mlíkovský 2009; Mierzwa-Szymkowiak \& Breure 2017). From the Peruvian material he collected, several new species were described, including birds, mammals, fishes, amphibians, insects, spiders, and molluscs (Taczanowski 1874, 1875; Mierzwa-Szymkowiak \& Breure 2017: supplementary material 2).

As part of our on-going studies on the Neotropical Philonthina and the examination of type and non-type material from European as well as North and South American museum collections, we have recently found two female specimens that belong to Ophionthus as defined by Chani-Posse (2014a). One of them, which was identified by us as $O$. serpentinus, is deposited in the Entomological Collection of the Museo de Historia Natural, Universidad Nacional Mayor de San Marcos, Lima, Peru (MUSM) and was collected by Hans-Wilhelm Koepcke (1914-2000) and Maria Koepcke (1924-1971), German zoologists who lived in Peru between 1950 and 1974 (Aguilar 2009). The second specimen is deposited in the Instituto Fundación Miguel Lillo, Tucumán, Argentina (IFML) and was collected by Wolfgang Karl Weyrauch (1907-1970), another German zoologist who lived in Peru from 1939 to 1961 and moved to Argentina - together with his private collection - in 1962 where he stayed until his death (Willink 1999).

The objectives of this paper are to redescribe Ophionthus and its type species, O. serpentinus, using characters from both external morphology and male and female genitalia, and to describe a new species, $O$. asenjoi sp. nov., based on female characters. Also, we provide the first specific collection locality for $O$. serpentinus and discuss the type locality, increasing the morphological and distributional data available for this genus. Finally, the systematic placement of Ophionthus within the Neotropical lineage of Philonthina is reassessed based on a phylogenetic analysis of morphology.

\section{Material and methods}

\section{Examination of specimens and terminology}

Rove beetles were examined as pinned dry specimens, relaxed in warm soapy water for five minutes, rinsed, then the last abdominal segments were dissected and cleared in $10 \% \mathrm{KOH}$ solution, washed in distilled water, and examined as wet preparations in glycerin. Dissections and observations were made using Nikon SMZ745 and Leica S6 D microscopes. The dissected segments were placed in polyethylene 
microvials with glycerin and pinned under the respective specimens. For detailed examination of the protarsomeres, the right foreleg of a female specimen was dissected from the body and prepared as follows: first, it was cleaned using an ultrasonic bath for three minutes, then the leg was dried, and lastly mounted on a metal stub using a Z-Axis electrically conductive tape and sputter-coated with gold. Micrographs were obtained using a JEOL JSM-6610LV scanning electron microscope. Photographs were taken using a Leica EC3 digital camera attached to the Leica S6 D microscope.

All measurements are in $\mathrm{mm}$. The following measurement abbreviations are used:

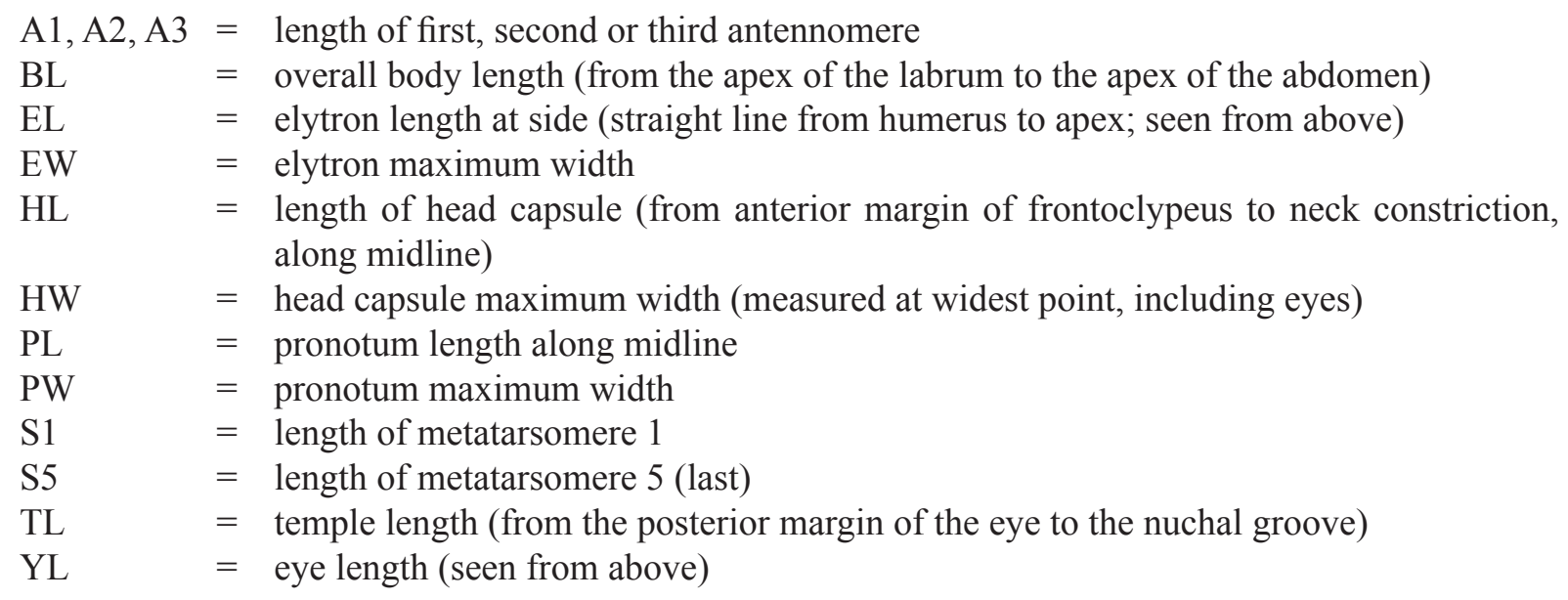

Terminology mainly follows Smetana (1995) and Chani-Posse (2014b). For the type material, information on the labels was written verbatim, quotation marks " "separate different labels, and a slash / separates different lines within a label. The text within square brackets [ ] is explanatory and/or inferred information and is not included on the original labels. Handwriting on labels of type specimens was compared to the respective author's handwriting using Horn et al. (1990).

\section{Depositories}

The type and non-type material studied here were borrowed from the following collections (collection managers and/or curators in parenthesis):

FMNH $=$ Field Museum of Natural History, Chicago, Illinois, USA (M. Turcatel, A.F. Newton, M.K. Thayer)

IFML = Entomological Collection of the Instituto Fundación Miguel Lillo, Tucumán, Argentina (Emilia Pérez)

MUSM $=$ Entomological Collection of the Museo de Historia Natural, Universidad Nacional Mayor de San Marcos, Lima, Peru (Diana Silva, Gerardo Lamas)

\section{Georeferencing of the type locality}

With the aim of tracing and georeferencing the type locality of $O$. serpentinus as well as that of our new species, O. asenjoi sp. nov., we used the Ornithological Gazetteers of Peru (Vaurie 1972; Stephens \& Traylor 1983), the Gazetteer of Peruvian entomological stations (Lamas 1976), documentation of Jelski's fieldwork and material collected in Peru (Taczanowski 1874, 1875, 1884; Mlíkovský 2009), as well as the catalogue of Weyrauch's type localities georeferenced (Breure 2012) and personal comments given by Dr Gerardo Lamas. Altitude, if it was not given by the original author, was extracted from Google Earth Pro (2020). We made a list of potential places that match with the type localities "Peruvia centralis" and "N-Peru: Bambamarca" in order to know the distribution of these species, summarized in the Supp. file 1. As for the female specimen of O. serpentinus, whose locality data is associated with the 
field collection code "Coll. Koepcke \#665" on its label, we referred to the catalogue of sampling sites of Koepcke (1982) which provides information about collecting places and field observations for more than 2000 sites in Peru. Maps were elaborated using QGIS (2020).

\title{
Phylogenetic analysis
}

In order to validate the taxonomic status of Ophionthus as a distinct genus of Philonthina and to confirm its monophyly and systematic placement within the Neotropical lineage, we included our new data (female characters for $O$. serpentinus) and the new species (O. asenjoi sp. nov.) into the original dataset by Chani-Posse \& Ramírez-Salamanca (2020a). From a total of 132 characters and 79 taxa, we found three coding errors in the original matrix (i.e., characters 6, 77 and 82) for O. serpentinus. Rectifications for this species are as follows: 6(1), antennomere 1 as long as or longer than antennomeres 2 and 3 combined; 77(0), protarsomeres 2 and 3 each as long as to longer than wide, and 82(0), discal setae without terminal plate. The resulting data matrix (see Supp. file 2) was analysed by means of maximum parsimony (MP) under the same previous conditions (Chani-Posse \& Ramírez-Salamanca 2020a).

\section{Results}

\section{Taxonomy}

\author{
Class Insecta Linnaeus, 1758 \\ Order Coleoptera Linnaeus, 1758 \\ Family Staphylinidae Latreille, 1802 \\ Subfamily Staphylininae Latreille, 1802 \\ Tribe Staphylinini Latreille, 1802 \\ Subtribe Philonthina Kirby, 1837
}

Genus Ophionthus Bernhauer, 1908

Figs 1-6

Ophionthus Bernhauer, 1908: 328.

Ophionthus - Bernhauer \& Schubert 1914: 372 (catalogue). — Lucas 1920: 461 (catalogue). Blackwelder 1944: 138 (checklist); 1952: 276. — Herman 2001: 2721 (catalogue). — ChaniPosse 2013: 10, 12, 14 (characters, phylogenetic placement); 2014a: 64, 68, 71, 76, 78 (characters, characters in key), 81, fig. 12h (habitus); 2014b: 252 (characters in data matrix). - Chani-Posse \& Solodovnikov 2017: 95 (characters). — Chani-Posse et al. 2018b: 50 (checklist). — Asenjo et al. 2019 (catalogue). - Chani-Posse \& Ramírez-Salamanca 2020a: 198, 209-210, 213-214 (taxon sampling, phylogenetic placement); 2020b: 238, 246 (discussion on characters and phylogenetic placement).

\section{Type species}

Ophionthus serpentinus Bernhauer, 1908, fixed by monotypy.

\section{Diagnosis}

The genus Ophionthus can be differentiated from other genera of Neotropical Philonthina by the combination of the following characters: head and pronotum broadened anteriad, antennomere 1 at least twice as long as 2 and almost as long as antennomeres 2 and 3 combined, labial palpomere 2 cylindrical, protarsomeres 2-3 with discal setae on ventral surface and without marginal setae, prosternum with sternacostal ridge joining superior line of hypomeron, metatarsomere 1 almost twice as long as 5 . 


\section{Redescription}

Dimensions. $\mathrm{BL}=10.5-11.6$. Body elongate, more or less parallel-sided, narrowing from seventh abdominal segment to apex (Figs 1A, 2A-B, 3A).

Colouration. Head, thorax, and abdomen shiny black to piceous, except apical half of tergum 7; apical third of sternum 7, and segments 8 and 9 yellow; mandibles, maxillary and labial palps, elytra, and legs dark brown; antennomeres 1-8 or 1-9 dark brown to black, 9-11 or 10-11 yellowish (Figs 1A, 2A-B, $3 \mathrm{~A})$.

HEAD. Subhexagonal and slightly transverse (male) to subquadrate (female) in shape, slightly broadened anteriad, narrower in female (Figs 2A, 3A) than male (Fig. 1A); nuchal ridge present; postmandibular ridge absent; postgenal ridge present; ventral basal ridge present, extending more or less parallel to ventral portion of postoccipital suture; infraorbital ridge present or absent; dorsal and ventral surface of head with scarce setation, microsculpture dense and undulate. Eyes large, moderately convex, occupying apical half of lateral margin of head, shorter than temples seen from above. Gular sutures joined before neck. Frontoclypeus with a short longitudinal groove. Antennae inserted closer to anterior margin of frontoclypeus than to eyes, moderately long, not reaching base of pronotum, increasing gradually in width toward apex; antennomere 1 without apical spine-like seta, distinctly longer than antennomere 2 and almost as long as antennomeres 2 and 3 combined; antennomere 3 slightly longer than antennomere 2; pubescence starting on antennomere 4 to 11 . Clypeus entire and fused with frons. Labrum rectangular, distinctly emarginate, sclerotized except apical margin, with several setae and macrosetae at apical margin. Mandible prominent, $1.4 \times$ length of head, with setose prostheca well-developed, with a groove on dorso-lateral margin. Maxilla with lacinia elongate and densely setose along internal apical half margin, with galea prominent and densely setose at apex; maxillary palpus long, palpomeres 1 to 4 glabrous with scarce setae at apices; palpomere 1 small; palpomere 2 slightly curved, longest, shorter than 3 and 4 combined; palpomere 4 cylindrical, longer than segment 3. Mentum transverse, with anterior margin slightly emarginate, one seta at each latero-lateral corner. Labial palpus moderately long; palpomere 1 shorter than 2; palpomere 2 shorter than 3; palpomere 3 cylindrical, shorter than 1 and 2 combined.

Pronotum. Distinctly longer than wide, slightly broadened anteriad, front margin subtruncate, hind margin slightly arcuate, anterior and posterior angles rounded (Figs 1A, 2A, 3A); disk with two dorsal rows of punctures sub-parallel to each other; lateral puncture of pronotum bearing long macroseta separated from superior line of pronotal hypomeron by a distance more than three times as large as diameter of puncture; surface with fine and dense microsculpture. Prosternum without distinct midlongitudinal carina; basisternum longer than furcasternum, with transverse carina variable (either complete or rudimentary). Mesoventrite somewhat elongate, with sternopleural suture distinctly oblique; mesoventral intercoxal process rounded, forming an obtuse angle.

LeGs. Profemora slightly narrowed toward apex, with lateroventral medial spines; protibiae setose, excavated; protarsomeres 1-4 longer than wide, slightly flattened dorsoventrally and slightly widened apically, with long and curved discal setae (adhesive setae) underneath, without marginal setae; mesoand metatarsomeres 1-2 with strong and distinct marginal setae (Fig. 3C); metatarsomere 1 moderately longer than 5 (Figs 1A, 2A, 3C).

ELYTRON. Longer than pronotum, subbasal ridge curved and projected anteriad, punctuation moderately coarse and homogeneously distributed. Hing wing with veins CuA and MP4 fused, vein MP3 present.

ABDomen. Tergum I with paired prototergal glands manifested by invaginated capsules with small openings. Terga III-V with anterior basal transverse carina distinct, posterior basal transverse carina 
always distinct on tergum III, distinct to not distinct on terga IV-V; area between anterior and posterior carinae deeply and sparsely punctate; surface with fine and dense microsculpture of transverse and oblique waves.

Male SeXual characters. Tergum VIII with apex projected medially, forming an obtuse angle (Fig. 1C); sternum VIII slightly emarginate apically (Fig. 1D). Genital segment with laterotergal sclerites IX short, not dorsoventrally flattened, with apex rounded and not sexually dimorphic (Fig. 2G); sternum IX symmetrical, deeply emarginate apically, with several fine and short setae at each side of emargination, basal portion moderately longer than distal portion (Fig. 1E); tergum X with apex rounded (Fig. 1F). Aedeagus with parameres fused as a short, triangular sclerite, and completely fused to median lobe (Fig. 1G-H); median lobe elongate with apical part narrowed into a rather broad apex (Fig. 1G-H).

Female seXual characters. Tergum VIII with apex projected medially forming an obtuse angle (Fig. 2E); sternum VIII with apex rounded (Fig. 2F); tergum X subtruncate (Fig. 2G); second gonocoxites each with a long macroseta proximally, with minute stylus bearing a long apical macroseta (Fig. $2 \mathrm{H}$ ).

\section{Immature stages}

Unknown.

\section{Geographical distribution}

The genus Ophionthus, with two species known at present, has been recorded from the departments of Cajamarca, La Libertad, and Junín in Peru. Based on the information of the specimen labels (locality and habitat), Ophionthus is distributed mainly in the ecoregion of Peruvian Yungas (Olson et al. 2001). However, according to Morrone's regionalization (2014) those localities belong to the biogeographical province of Puna (Figs 4-5, Supp. file 1).

\section{Bionomics}

The species of Ophionthus are considered general predators as are the other genera of Philonthina. One specimen of $O$. serpentinus was collected in a clearing in montane forest and riverside shrubbery.

\section{Ophionthus serpentinus Bernhauer, 1908}

Figs 1-2, 4-6

Ophionthus serpentinus Bernhauer, 1908: 329.

Ophionthus serpentinus - Bernhauer \& Schubert 1914: 372 (catalogue). — Lucas 1920: 461 (catalogue). - Blackwelder 1944: 138 (checklist); 1952: 276 (type species: O. serpentinus). - Herman 2001: 2721 (catalogue). - Chani-Posse 2014a: 81, fig. 12h (habitus); 2014b: 252 (characters in data matrix). - Chani-Posse et al. 2018b: 51 (checklist). - Asenjo et al. 2019 (catalogue). Chani-Posse \& Ramírez-Salamanca 2020a: 198, 209-210, 213-214 (taxon sampling, phylogenetic placement); 2020b: 238, 246 (discussion on characters and phylogenetic placement).

\section{Material examined}

\section{Holotype}

PERU - $\widehat{O}$ [specimen glued to the tip of a triangle of white card]; "Xanthopygus sp. / Perú central 1873. / C. Jelski [handwriting on white label]", "Peruvia centr. / lg. Jelski 1873 / ded. [latin dedit= gave] Skalitzky. [Bernhauer's handwriting on white label]", "Ophionthus / serpentinus / Brh. Typus. [Bernhauer's handwriting on brown label]", "Chicago NHMus / M. Bernhauer / Collection [printed on white label]"; FMNH. 

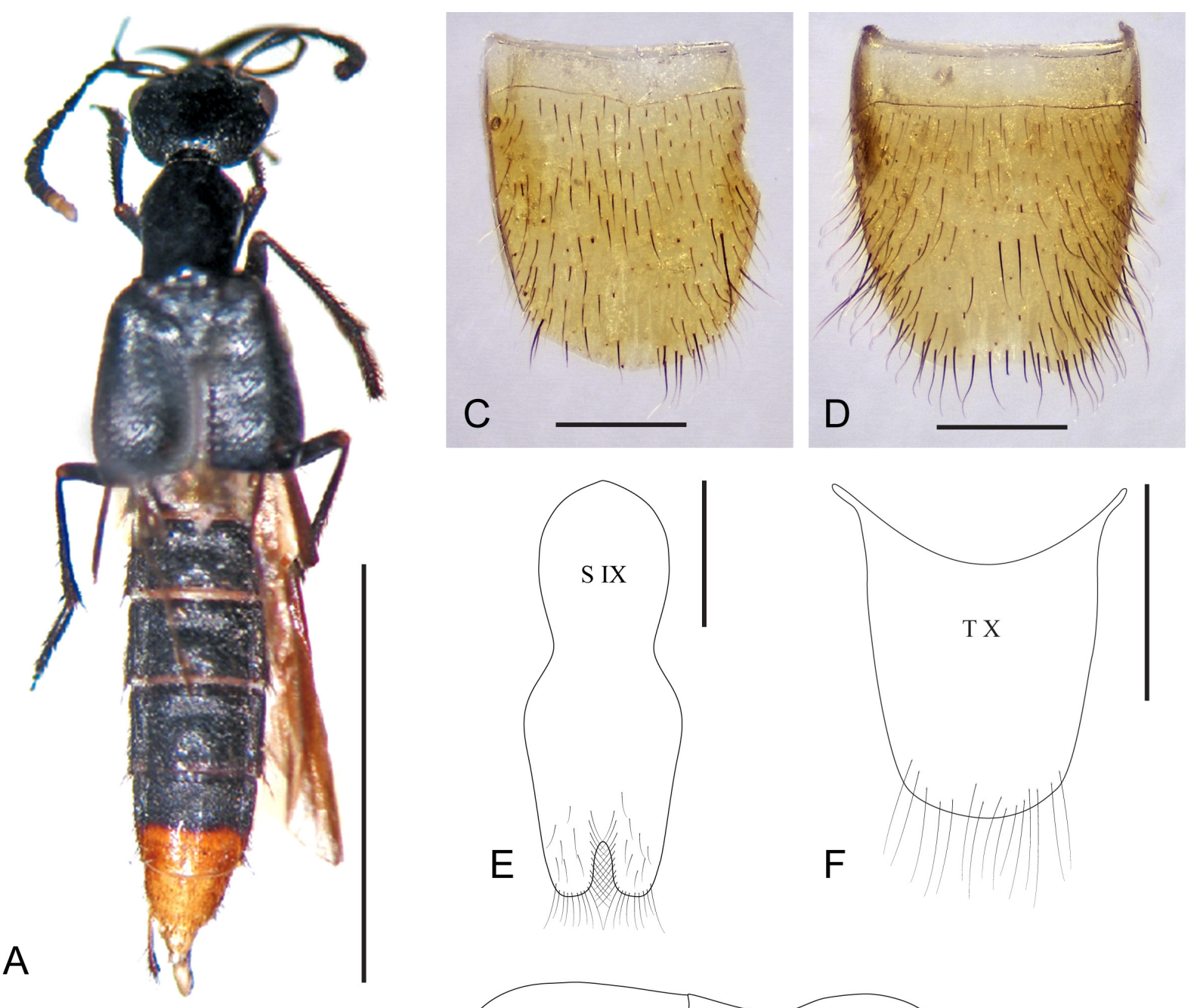

A
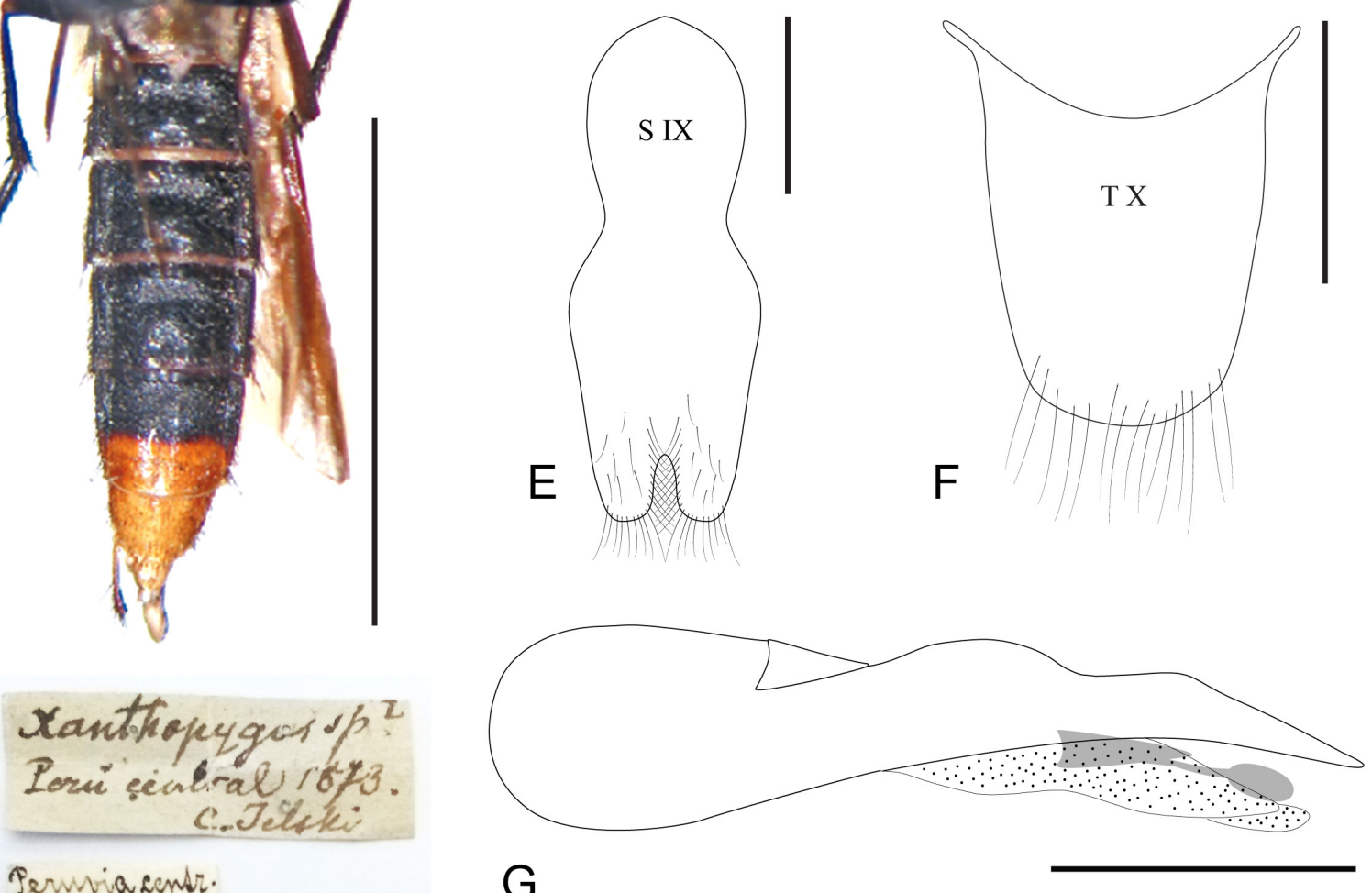

Pervivia cendr.

eg. Hels $\operatorname{kin} 18 \times 3$

ded. Skatilakly.

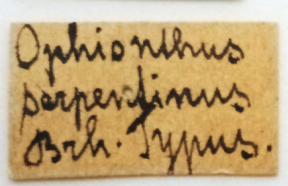

Chicago NHMus

M.Bernhauer

$\mathrm{B}$

Collecrion

Fig. 1. Ophionthus serpentinus Bernhauer, 1908. Holotype, $\widehat{\jmath}$ (FMNH). A. Habitus, dorsal view, after Chani-Posse (2014a). B. Original labels. C. Tergum VIII. D. Sternum VIII. E. Sternum IX. F. Tergum X. G. Aedeagus, lateral view. H. Aedeagus, dorsal view. Stippled areas in G represent membranes. Shadded areas in $\mathrm{G}$ and $\mathrm{H}$ represent internal sclerites Scale bars: $\mathrm{A}=5 \mathrm{~mm}$; $\mathrm{C}-\mathrm{H}=0.5 \mathrm{~mm}$. 


\section{Comments}

Bernhauer (1908) stated that Skalitzky gave him a unique specimen of $O$. serpentinus; the specimen mentioned above agrees with the original description and is considered to be the holotype, fixed by monotypy.

\section{Other material}

PERU - La Libertad - 1 [ [specimen glued to the tip of a triangle of white card]; LL [La Libertad], Quebrada Borgapampa, Hda. [Hacienda] Llaguén; ca $7^{\circ} 40^{\prime} \mathrm{S}, 78^{\circ} 40^{\prime} \mathrm{W}$; ca $1800 \mathrm{~m}$ [m a.s.1.]; 12 Dec. 1952; H-W. Koepcke \& M. Koepcke leg.; a clearing in montane forest and riverside shrubbery; Coll. Koepcke \#665; MUSM.

\section{Diagnosis}

Ophionthus serpentinus differs from $O$. asenjoi sp. nov. by having the head with two pairs of interocular punctures, antennae with the last two antennomeres much lighter than the preceding segments (Figs 1A, $2 \mathrm{~A}-\mathrm{B}$ ) and the abdominal terga III-V each with a distinct posterior basal transverse carina.

\section{Redescription}

Dimensions. BL=11.3-1.6 (Figs 1A, 2A-B).

Colouration. Head, thorax, and abdomen shiny black, except apical half of tergum VII, apical third of sternum VII, and segments VIII and IX yellow; mandibles, maxillary and labial palps, elytra, and legs dark brown; antennomeres 1-9 dark brown to black and 10-11 yellowish (Figs 1A, 2A-B).

HeaD. As wide as long (female) (Fig. 2A) to wider than long (male) (Fig. 1A) (HW/HL=1.0-1.2) and moderately wider than pronotum $(\mathrm{HW} / \mathrm{PW}=1.2-1.4)$. Eyes moderately shorter than temples $(\mathrm{YL} / \mathrm{TL}=$ 0.5-0.6) seen from above. Epicranium with 2 pairs of interocular punctures; each side of vertex with 4-5 postocular punctures. Antennae with antennomere 1 at least $2 \times$ as long as antennomere $2(\mathrm{~A} 1 / \mathrm{A} 2=$ 2.1-2.6) and almost as long as antennomeres 2 and 3 combined $(\mathrm{A} 1 /(\mathrm{A} 2+\mathrm{A} 3)=0.9-1.1)$, antennomere 2 moderately shorter than antennomere $3(\mathrm{~A} 2 / \mathrm{A} 3=0.8)$. Labial palpus with palpomere $21.4 \times$ as long as palpomere 1 and $0.6 \times$ as long as palpomere 3 . Maxillary palpus with palpomere 1 distinctly short; palpomere 2 curved, $2 \times$ as long as palpomere 3 ; palpomere 4 slightly longer than palpomere $2,2 \times$ as long as palpomere 3 . Neck about $0.4 \times$ as wide as head at widest point.

Pronotum. Longer than wide (PL/PW $=1.2-1.3)$, with two dorsal rows of 4 punctures each on disk of pronotum, 3-4 sublateral punctures.

LEGs. First metatarsomere longer than fifth $(\mathrm{S} 1 / \mathrm{S} 5=1.8)$ (Fig. 2A).

ELYTRON. Longer than wide $(\mathrm{EL} / \mathrm{EW}=1.8)$, at sides about $1.6 \times$ as long as elytron along suture.

ABDOMEN. Abdominal terga III-V each with posterior basal transverse carina distinct.

Male SeXUAl Characters. Tergum VIII with hind margin projected, forming an obtuse angle (Fig. 1C). Sternum VIII slightly emarginate apically at middle, with numerous long setae on apical area and small setae on basal area (Fig. 1D). Sternum IX symmetrical, narrowed in the middle of its lateral margins, deeply emarginate apically, with several fine and short setae at each side of emargination (Fig. 1E). Tergum $X$ with apex rounded, with numerous setae at apex (Fig. 1F). Aedeagus with median lobe distinctly broadened at middle and gradually narrowed towards a rather truncate apex seen from above, paramere triangular with base concave (Fig. 1G-H), internal sclerites as in Fig. 1G-H.

Female SeXual ChaRActers. As described for the genus. 

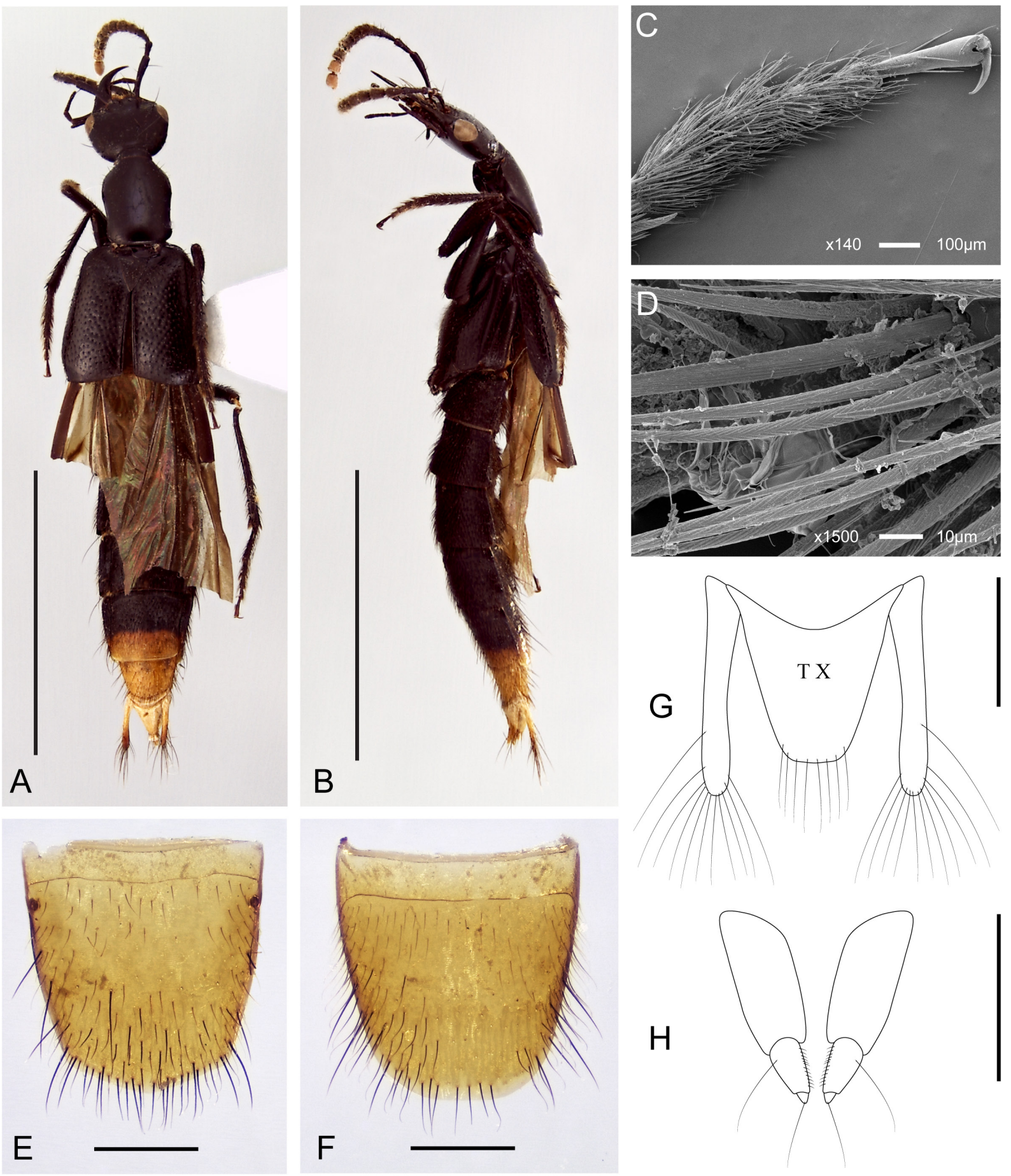

Fig. 2. Ophionthus serpentinus Bernhauer, 1908. ( (MUSM). A. Habitus, dorsal view. B. Habitus, lateral view. C. Right protarsomeres, ventral view. D. Details of discal setae from right third protarsomere, ventral view. E. Tergum VIII. F. Sternum VIII. G. Lateral tergal sclerites IX and tergum X. H. Gonocoxites of female genital segment. Scale bars: A-B $=5 \mathrm{~mm}$; $\mathrm{G}-\mathrm{H}=0.5 \mathrm{~mm}$. 


\section{Geographical distribution and bionomics}

The male holotype of O. serpentinus was collected in 1873 by Jelski in "Peruvia centralis" (Fig. 1B). Jelski travelled and collected in the central Andes of Peru during that year (Solsky 1875; Taczanowski 1875; Mlíkovský 2009) and the localities he visited are summarized in the Supp. file 1 and Figs 4-5. Based on these analyses, the type locality "Peruvia centralis" is located in the department of Junín, but we do not have more information (e.g., day and/or month of collection) to improve the accuracy of this type locality (Fig. 1B). Additionally, the new locality provided by the female specimen from Hacienda Llaguén, ca $7^{\circ} 40^{\prime} \mathrm{S}, 78^{\circ} 40^{\prime} \mathrm{W}, 1800 \mathrm{~m}$ [m a.s.1.] (Koepcke 1982) is located in the department of La Libertad and close to the Forest of Llaguén $\left(7^{\circ} 42^{\prime} \mathrm{S}, 78^{\circ} 44^{\prime} \mathrm{W}, 2642 \mathrm{~m}\right.$ [m a.s.1.]), which is described as a dry cloud forest, with high human disturbance and used for grazing cattle and as a source of fuel (Valencia 1990). Hacienda Llaguén is placed in the ecoregion of Peruvian Yungas (Olson et al. 2001) or in the Puna province (Morrone 2014) (Fig. 4) and nowadays it is placed in the ecosystem of Andean shrublands (MINAM 2019). According to label information, the female specimen was collected in an open area within a montane forest and riverside shrubbery.

Ophionthus asenjoi sp. nov.

urn:lsid:zoobank.org:act:F332981B-C75D-4420-824B-B1729C3B1FC6

Figs $3-4,6$

\section{Diagnosis}

Ophionthus asenjoi sp. nov. differs from $O$. serpentinus by having the head with one pair of interocular punctures, antennae with the last three antennomeres much lighter than the preceding segments (Fig. 3A) and the abdominal terga IV and V each without a distinct posterior basal transverse carina.

\section{Etymology}

This new species is dedicated to the outstanding Peruvian coleopterist Angélico Asenjo, a great friend and colleague, in recognition of his tireless contribution to the study of Staphylinidae from Latin America and other regions, and as a small gesture of thanks for his continuous support of and collaboration with the first author, MR. This specific epithet is regarded as a Latinized masculine noun in the genitive case.

\section{Material examined}

\section{Holotype}

PERU • O [specimen glued to a white strip]; "N-PERU: / Bambamarca, / 3000m, 28.VI[June]. [19]56 / leg. W. Weyrauch" [typewritten on white label], "ex- col / Weyrauch [printed on white label with black borders]", "COLECCION / Fundación M. Lillo / 4000 S. M. Tucumán / TUCUMAN - ARGENTINA [printed on white greenish label]", "HOLOTYPE / Ophionthus asenjoi / Rodríguez-Melgarejo \& / Chani-Posse 2020 [printed on red label]"; IFML.

\section{Description}

Dimensions. $\mathrm{BL}=10.5$ (Fig. 3A).

Colouration. Head, thorax, and abdomen piceous, except apical half of tergum VII, apical third of sternum VII, and segments VIII and IX yellow; mandibles, maxillary and labial palps, elytra and legs dark brown; antennomeres 1-8 dark brown to black and 9-11 yellowish (Fig. 3A).

HEAD. Wider than long $(\mathrm{HW} / \mathrm{HL}=1.2)$, moderately wider than pronotum $(\mathrm{HW} / \mathrm{PW}=1.2)$. Eyes moderately shorter than temples $(\mathrm{YL} / \mathrm{TL}=0.8)$ seen from above. Epicranium with one pair of interocular punctures; each side of vertex with $4-5$ postocular punctures. Antennae with antennomere 1 more than $2 \times$ as long 
as antennomere $2(\mathrm{~A} 1 / \mathrm{A} 2=2.2)$ and as long as antennomeres 2 and 3 combined $(\mathrm{A} 1 /(\mathrm{A} 2+\mathrm{A} 3)=1)$, antennomere 2 distinctly shorter than antennomere $3(\mathrm{~A} 2 / \mathrm{A} 3=0.7)$. Labial palpus with palpomere $21.4 \times$ as long as palpomere 1 and $0.6 \times$ as long as palpomere 3 . Maxillary palpus with palpomere 1 distinctly short; palpomere 2 curved, $2 \times$ as long as palpomere 3 ; palpomere 4 slightly longer than palpomere 2 and about $2 \times$ as long as palpomere 3 . Neck about $0.4 \times$ as wide as head at widest point.
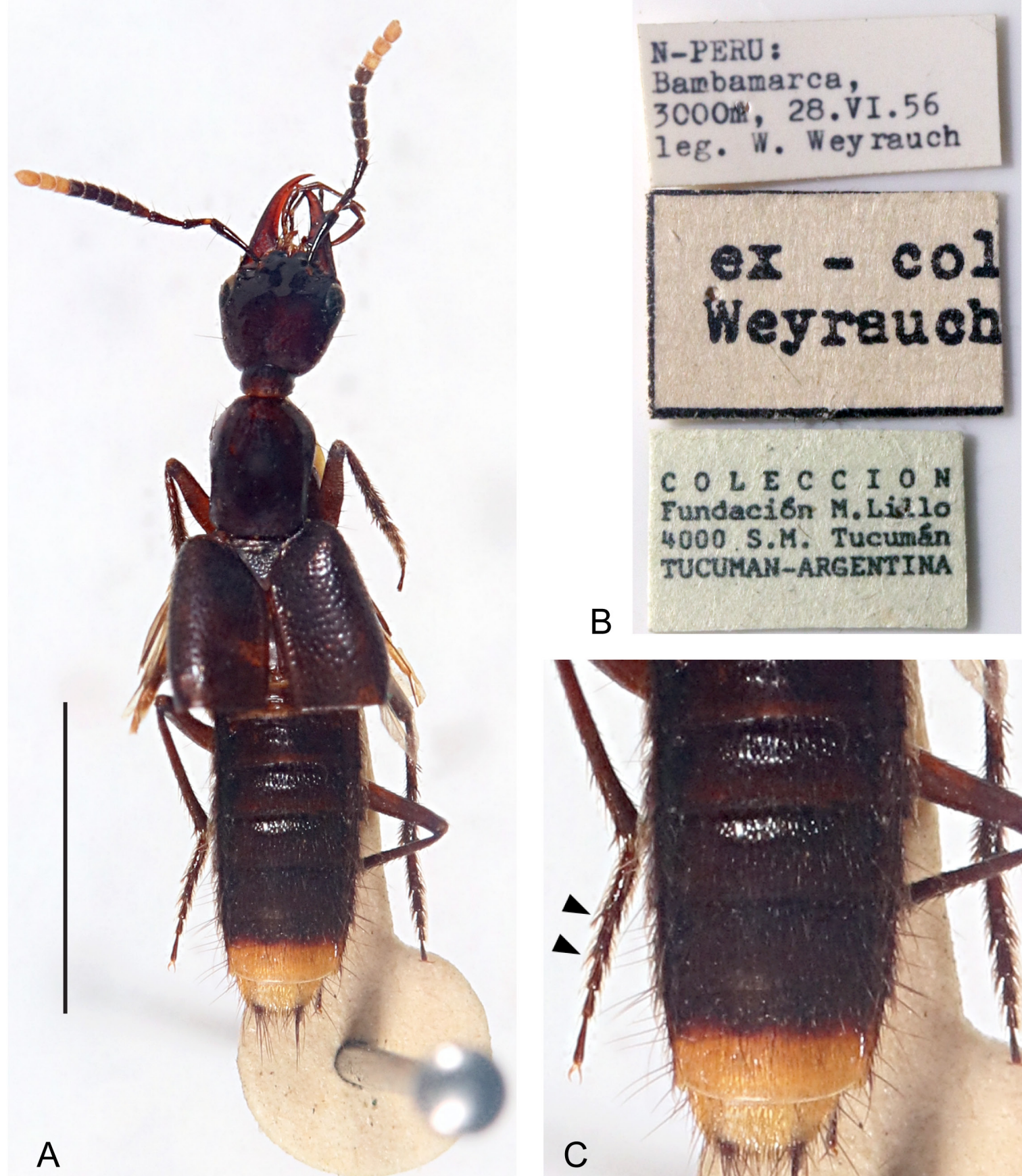

\section{B}

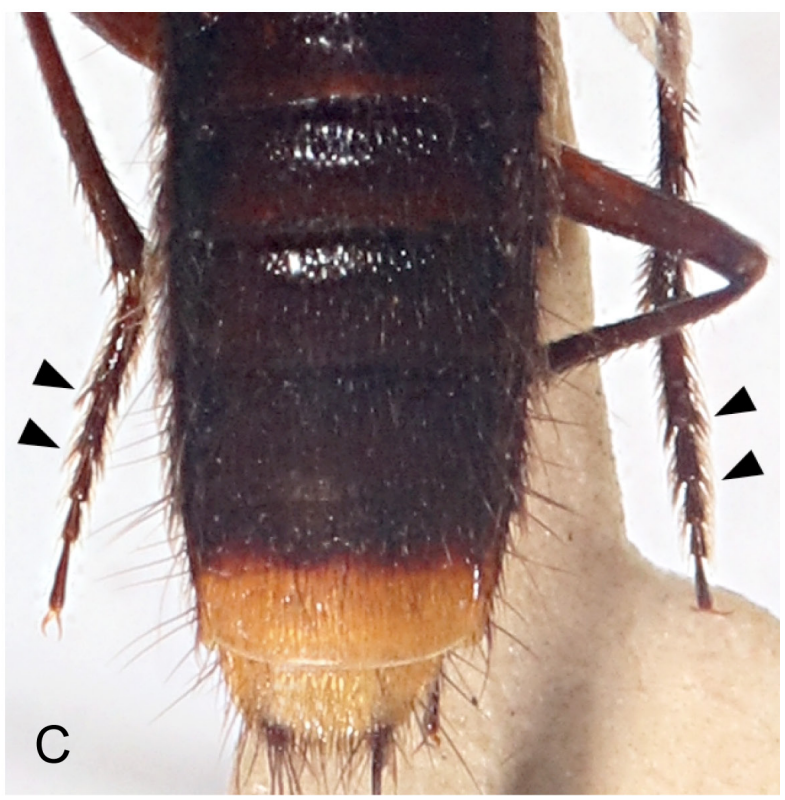

Fig. 3. Ophionthus asenjoi sp. nov. Holotype, $q$ (IFML). A. Habitus, dorsal view. B. Original labels. C. Metatarsomeres 1 and 2 with strong and distinct marginal setae (arrows). Scale bar $=5 \mathrm{~mm}$. 
Pronotum. Longer than wide $(\mathrm{PL} / \mathrm{PW}=1.3)$, with two dorsal rows of four punctures each on disk of pronotum, 3-4 sublateral punctures.

Legs. First metatarsomere longer than fifth $(\mathrm{S} 1 / \mathrm{S} 5=1.7)$ (Fig. 3C).

ELYTRON. Longer than wide $(\mathrm{EL} / \mathrm{EW}=1.6)$, at sides about $1.6 \times$ as long as elytron along suture.

AвDOMEN. Posterior basal transverse carina distinct only on tergum III.

MALE SEXUAL CHARACTERs. Unknown.

Female sexual characters. Similar to those of $O$. serpentinus.

\section{Geographical distribution and bionomics}

Ophionthus asenjoi sp. nov. is only known at present from its type locality in Bambamarca, department of Cajamarca, Northern Peru at $3000 \mathrm{~m}$ [m a.s.l.] (Fig. 4). In addition, it is known that on the same collection day as that of the holotype of $O$. asenjoi sp. nov. (i.e., 28 Jun. 1956), Weyrauch collected two specimens of Cajamarca triseriata Roewer, 1957 (Arachnida: Opiliones) in "Nord-Peru: Cerro Macheipungo, $4 \mathrm{~km} \mathrm{NW}$ Bambamarca" (Roewer 1957: 75), which is georeferenced as $06^{\circ} 41^{\prime} \mathrm{S}$, $78^{\circ} 32^{\prime} \mathrm{W}$ (Breure 2012: 5). Therefore, it is highly probable that this locality is the same or close to where the holotype of $O$. asenjoi sp. nov. was collected. Bambamarca belongs to the ecoregion of Peruvian Yungas (Olson et al. 2001) or Puna province (Morrone 2014) and is nowadays agricultural land, surrounded by an urban zone and Andean shrubland ecosystem (MINAM 2019).

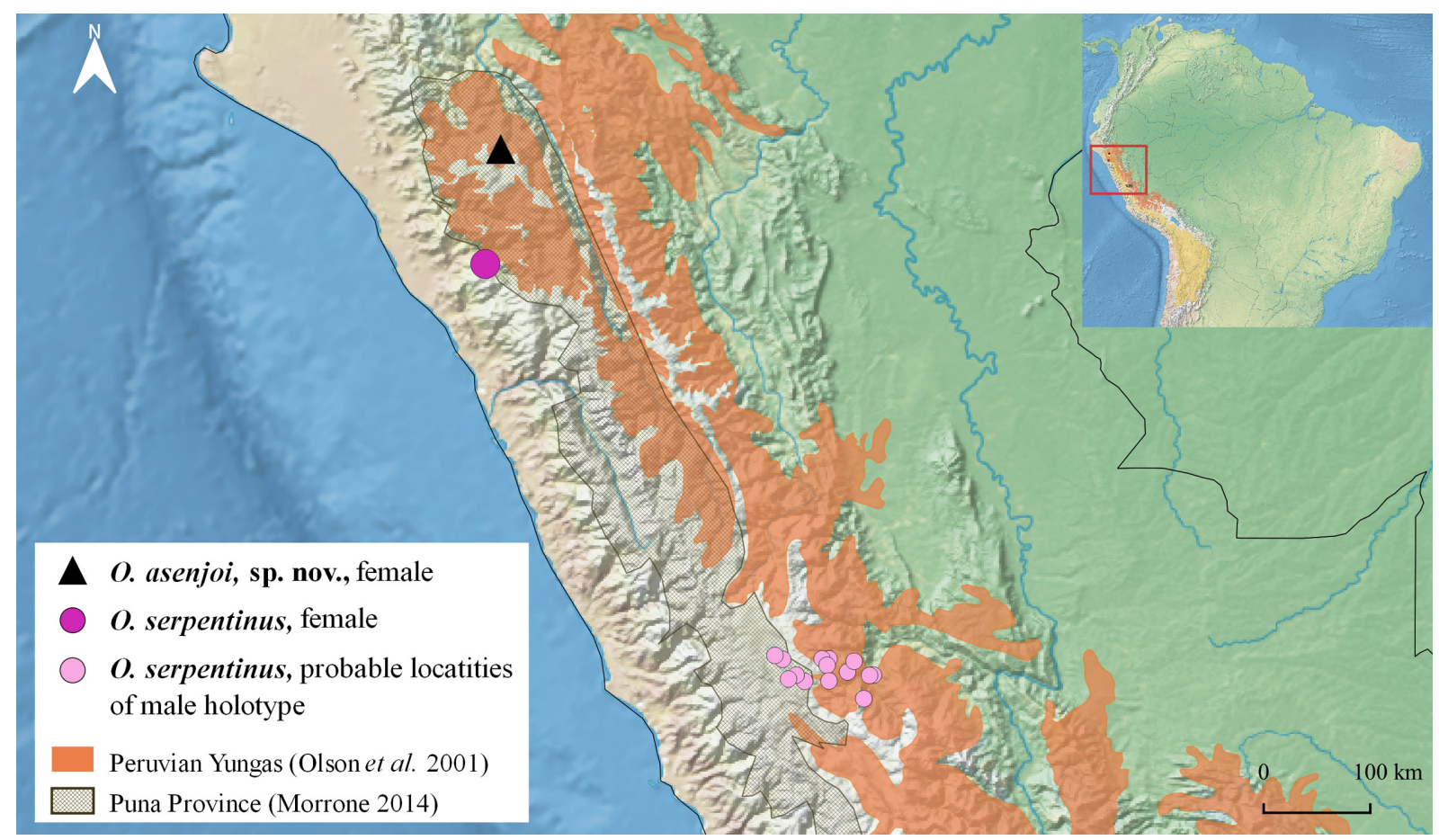

Fig. 4. Distribution map of Ophionthus serpentinus Bernhauer, 1908 and O. asenjoi sp. nov. 


\section{Discussion}

After reviewing most of the available type and non-type material of Philonthina from the main collections in Europe, North and South America, we found only three specimens of Ophionthus, one of them being the male holotype of the type species, $O$. serpentinus. The two additional specimens are a female of $O$. serpentinus (MUSM) and another female of $O$. asenjoi sp. nov. (IFML), both collected in Peru in 1952 and 1956, respectively. The holotype of O. serpentinus was also collected in Peru, in 1873, and represents the oldest known collected specimen of Ophionthus. Based on this evidence, we confirm that the two species of Ophionthus are collected very rarely and in small numbers. The rarity could be due to low population densities, lack of collecting effort and/or a difficult-to-sample microhabitat (i.e., flowers or vegetation), changes in anthropic land use (the collecting site of $O$. asenjo $i$ sp. nov. now consists of agricultural and urban lands), or a combination of these causes.

The previous systematic assessment by Chani-Posse \& Ramírez-Salamanca (2020a) placed Ophionthus into the so-called Paederomimus complex of the Neotropical lineage of Philonthina. Although not related to any of the clades that contain the type species of the most diverse but not monophyletic genera of Philonthina in CASA (i.e., Belonuchus Nordmann, 1837, Paederomimus Sharp, 1885, Philonthus Stephens, 1829), Ophionthus appeared not far from the Musicoderus clade in that study, i.e., in a wellsupported sister group relationship with Belonuchus barbicornis Bernhauer, 1916, a species only known from the Andes of Colombia. Our new assessment herein does not only confirm Ophionthus as a member of the Neotropical lineage and the Paederomimus complex, but it also validates its status as a distinct genus (Fig. 6). Furthermore, its former close relationships to B. barbicornis and other previously allied taxa are not supported here, and their phylogenetic relationships within the Paederomimus complex remain unclear. Thus, Ophionthus is revealed as a morphologically distinct genus within the Neotropical lineage.

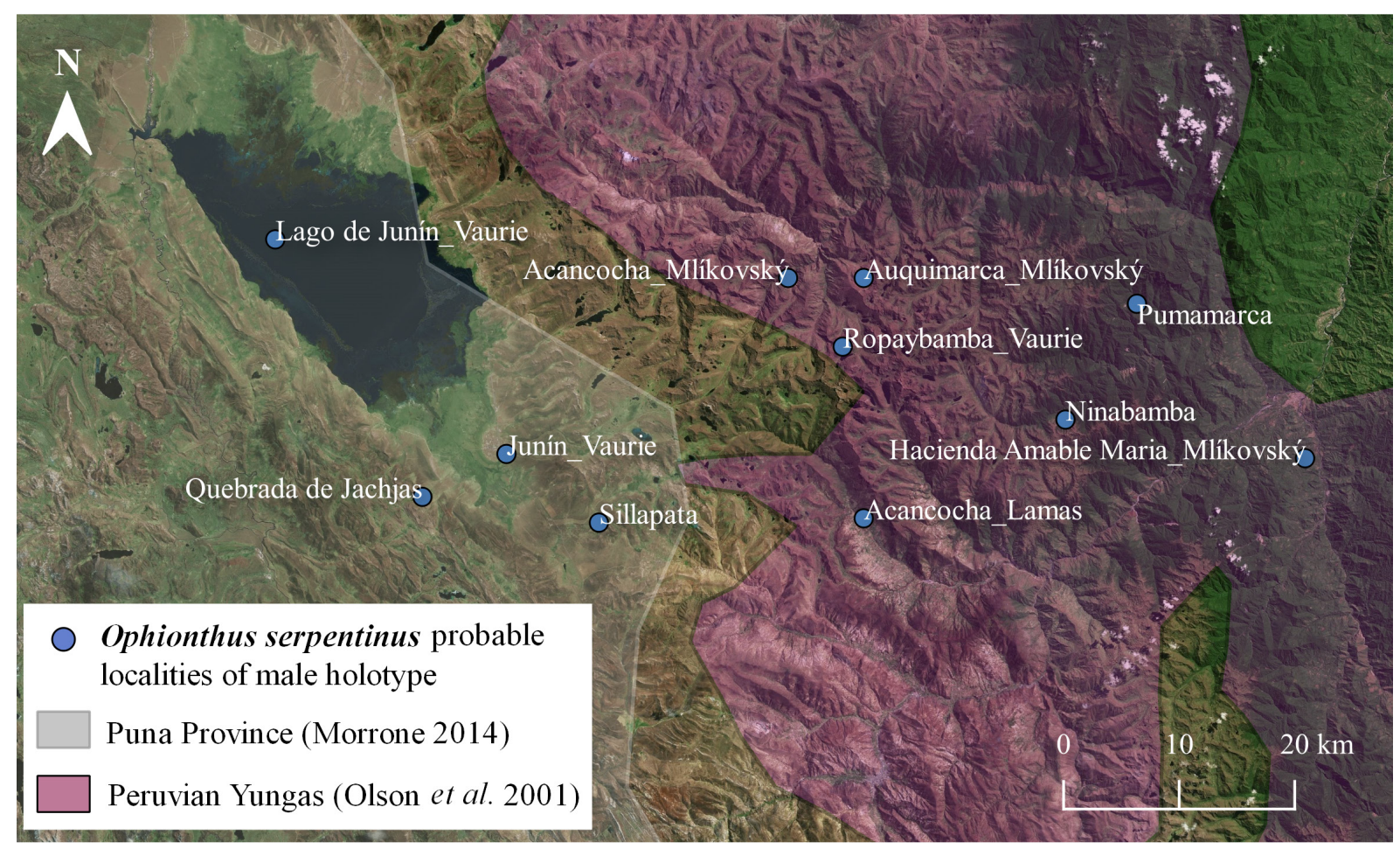

Fig. 5. Map of probable localities (correct spelling, see Supp. file 1) for the male holotype of Ophionthus serpentinus Bernhauer, 1908 collected in "Peruvia centralis" by Jelski in 1873. 


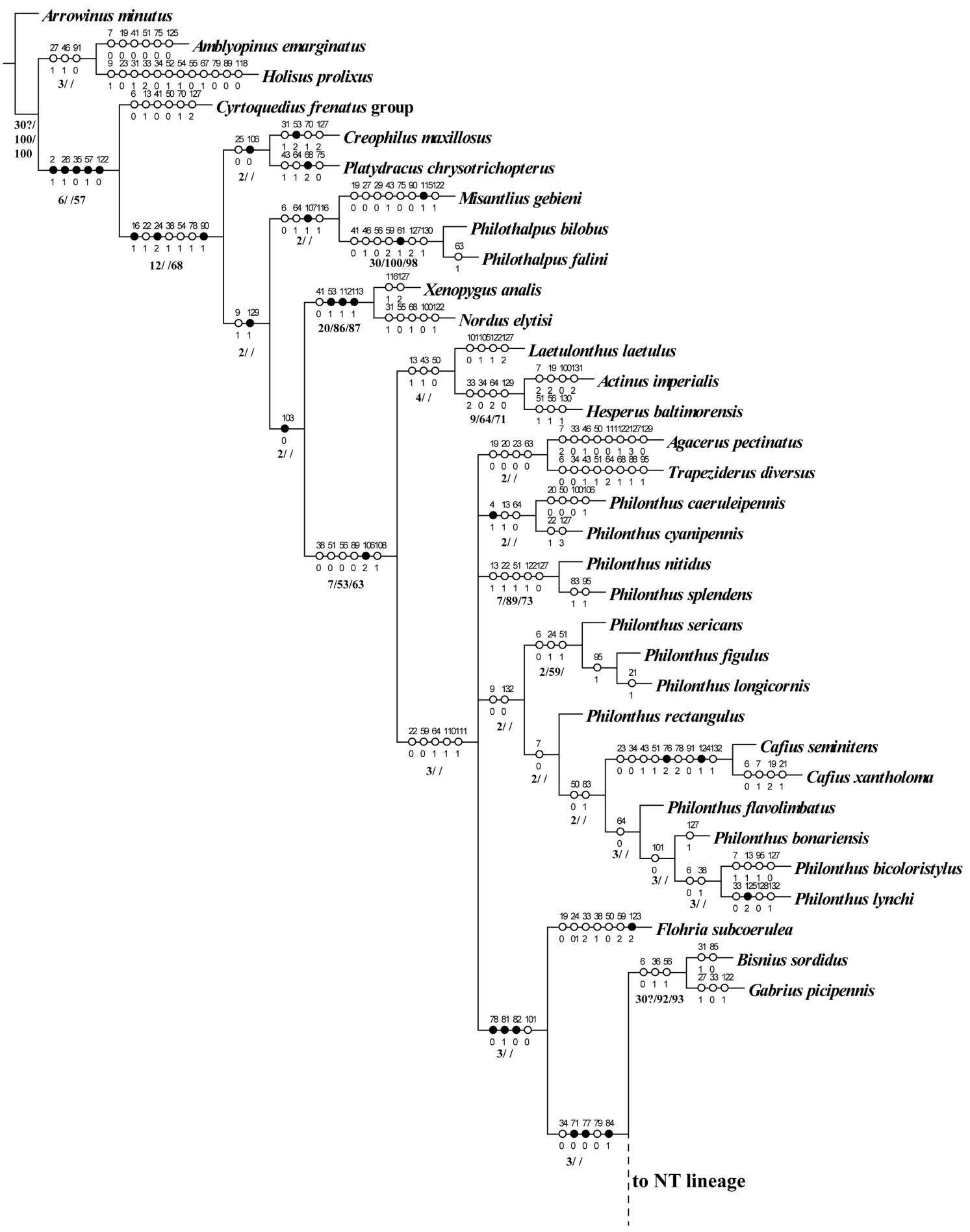

Fig. 6 (continued on next page). Strict consensus of the 28 MP trees obtained showing the systematic placement of Ophionthus Bernhauer, 1908 within the Neotropical lineage of Philonthina Kirby, 1837 (tree length $=579$; consistency index $(\mathrm{CI})=0.24$; retention index $(\mathrm{RI})=0.71$. Black circles: exclusive synapomorphies; open circles, non-exclusive synapomorphies. Numbers above circles are character numbers; numbers below circles represent character states. Support values are indicated in bold below the branches as follows: Bremer/Standard Bootstrap/Jack-knife (cut $=50$ for resampling support values). 


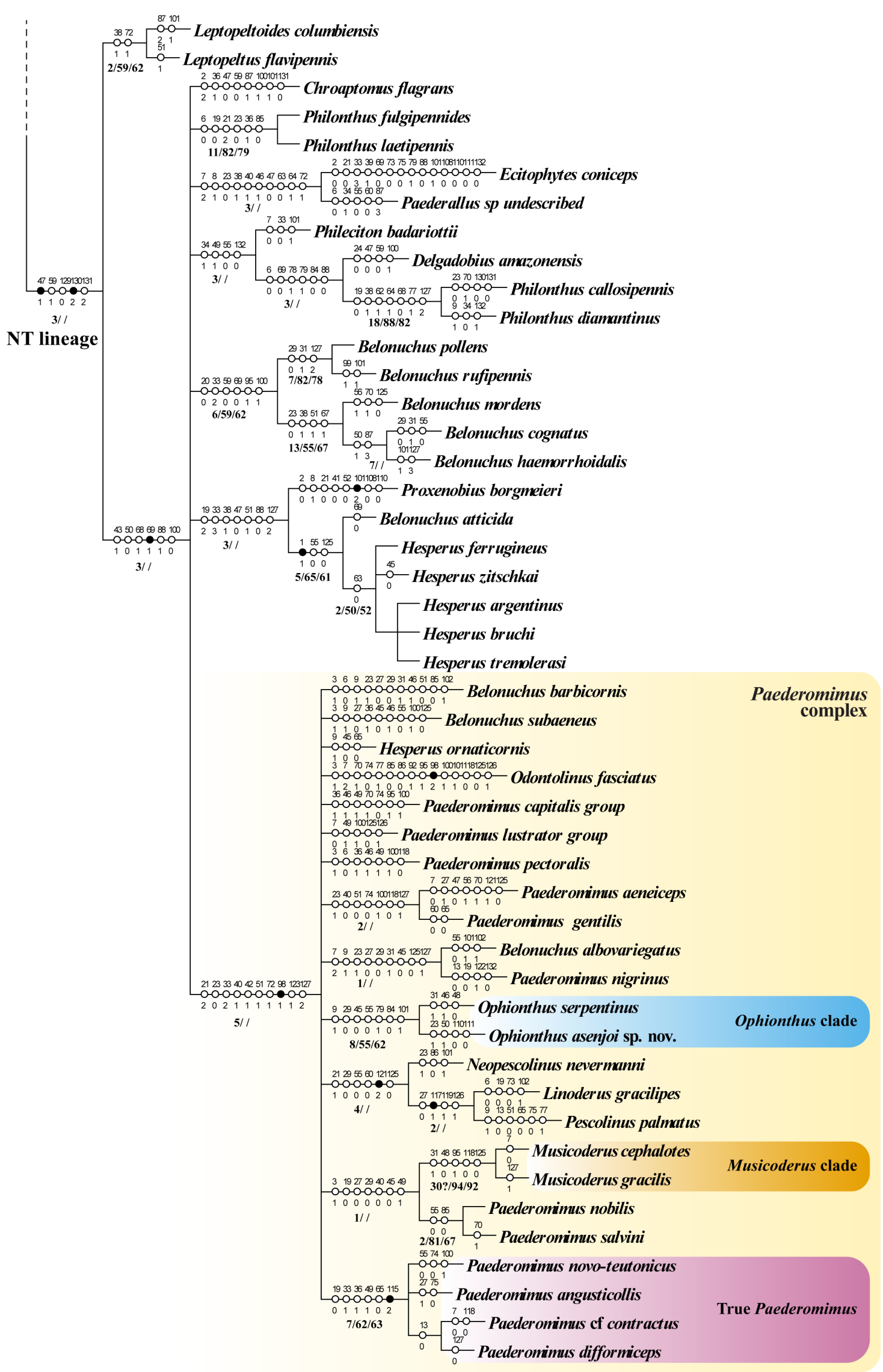




\section{Acknowledgements}

We are grateful to Gerardo Lamas (MUSM), Diana Silva (MUSM) and Sergio Roig (IADIZA) for allowing MR to use their laboratory facilities during this research. We are very grateful to Angélico Asenjo by giving us access to his database. Special thanks to Silvina Lassa (IANIGLA) for her technical support with obtaining the micrographs, and Angélico Asenjo, Gerardo Lamas and the anonymous reviewers for useful comments that improved the manuscript. The first author (MR) thanks Luis Pérez for his continuous support and trust. We are grateful to all the members of the Laboratory of Entomology (IADIZA), specially: Sergio Roig, Gustavo Flores, José Ramírez, Sofia Copperi, Belén Maldonado, Mariana Griotti, Ana María Scollo and Florencia Fernández, with whom MR shared great moments during her internship at IADIZA. In addition, we want to thank the Biodiversity Heritage Library for being an extraordinary source of natural history literature. Funding for this project was primarily provided by Programa Nacional de Innovación Agraria, Ministerio de Agricultura del Perú (N 196-2018-INIA-PNIA-PASANTÍA) granted to the first author (MR). The second author (MCP) was supported by CONICET and FONCYT through PICT 2015-1016.

\section{References}

Aguilar P.G. 2009. Comentarios sobre el desarrollo de la Zoología en la Facultad de Ciencias Biológicas de la Universidad Nacional Mayor de San Marcos. Revista Peruana de Biología 15 (2): 7-14. https://doi.org/10.15381/rpb.v15i2.1695

Asenjo A., Irmler U., Klimaszewski J., Chandler D.S., Fierros-López H.E. \& Vieira J.S. 2019. Staphylinidae (Insecta: Coleoptera) in Latin America: synopsis, annotated catalog, diversity and distribution. Zootaxa 4621 (1): 1-406. https://doi.org/10.11646/zootaxa.4621.1.1

Bernhauer M. 1908. Beitrag zur Staphylinidenfauna von Südamerika. Archiv für Naturgeschichte 74 (1): 283-372. Available from https://www.biodiversitylibrary.org/part/226088\#/summary [accessed 28 Jan. 2021].

Bernhauer M. \& Schubert K. 1914. Staphylinidae IV. In: Schenkling S. (ed.) Coleopterorum Catalogus Vol. 57: 289-408. W. Junk, Berlin.

Blackwelder R.E. 1944. Checklist of the coleopterous insects of Mexico, Central America, the West Indies, and South America. Part. 1. Bulletin of the United States National Museum 185: 1-188.

https://doi.org/10.5479/si.03629236.185.i

Blackwelder R.E. 1952. The generic names of the beetle family Staphylinidae, with an essay on genotypy. Bulletin of the United States National Museum 200: 1-483.

Available from https://www.biodiversitylibrary.org/part/85283\#/summary [accessed 28 Jan. 2021]

Breure A. 2012. Weyrauch's type localities: a clarification; with illustrations of types of Orthalicoidea (Mollusca, Gastropoda, Stylommatophora) in the Tucumán museum. Folia Conchyliologica 17: 4-24.

Chani-Posse M.R. 2013. Towards a natural classification of the subtribe Philonthina (Coleoptera: Staphylinidae: Staphylinini): a phylogenetic analysis of the Neotropical genera. Systematic Entomology 38 (2): 390-406. https://doi.org/10.1111/syen.12003

Chani-Posse M.R. 2014a. An illustrated key to the New World genera of Philonthina Kirby (Coleoptera: Staphylinidae), with morphological, taxonomical and distributional notes. Zootaxa 3755 (1): 62-86. https://doi.org/10.11646/zootaxa.3755.1.3

Chani-Posse M.R. 2014b. Systematics and phylogeny of the Neotropical genera Pescolinus Sharp and Neopescolinus gen. n. (Coleoptera: Staphylinidae). Arthropod Systematics \& Phylogeny 72 (3): 227 255. Available from https://ri.conicet.gov.ar/handle/11336/33903 [accessed 28 Jan. 2021]. 
Chani-Posse M.R. \& Ramírez-Salamanca J.M. 2020a. To be biased or to be Neotropical: systematic reassessment of a megadiverse lineage of rove-beetles (Philonthina, Staphylinini, Staphylininae). Cladistics 36 (2): 194-217. https://doi.org/10.1111/cla.12395

Chani-Posse M.R. \& Ramírez-Salamanca J.M. 2020b. Konradus leehermani - a new genus and species of Philonthina from the Neotropical region and its phylogenetic relationships (Coleoptera: Staphylinidae: Staphylininae). Zootaxa 4759 (2): 237-251. https://doi.org/10.11646/zootaxa.4759.2.6

Chani-Posse M.R. \& Solodovnikov A. 2017. Tackling generic limits for the Neotropical Philonthina with a phylogenetic approach: revision of the genera Linoderus Sharp and Odontolinus Sharp (Coleoptera: Staphylinidae). Arthropod Systematics \& Phylogeny 75 (1): 83-97.

Chani-Posse M.R., Brunke A.J., Chatzimanolis S., Schillhammer H. \& Solodovnikov A. 2018a. Phylogeny of the hyper-diverse rove beetle subtribe Philonthina with implications for classification of the tribe Staphylinini (Coleoptera: Staphylinidae). Cladistics 34 (1): 1-40. https://doi.org/10.1111/cla.12188

Chani-Posse M.R., Newton A., Kappel Hansen A. \& Solodovnikov A. 2018b. Checklist and taxonomic changes for Central and South American Philonthina (Coleoptera: Staphylinidae). Zootaxa 4449 (1): 1-95. https://doi.org/10.11646/zootaxa.4449.1.1

Google Earth Pro. 2020. Google Earth 7.3.3.

Available from https://www.google.com/intl/es/earth/download/gep/agree.html [accessed 12 May 2020]

Herman L.H. 2001. Catalog of the Staphylinidae (Insecta: Coleoptera). 1758 to the end of the second millennium. V. Staphylinine Group (Part 2) Staphylininae: Diochini, Maorothiini, Othiini, Platyprosopini, Staphylinini (Amblyopinina, Anisolinina, Hyptiomina, Philonthina). Bulletin of the American Museum of Natural History 265: 2441-3020. https://doi.org/10.1206/0003-0090.265.1.5

Horn W., Kahle I., Friese G. \& Gaedike R. 1990. Collectiones Entomologicae. Ein Kompendium über den Verbleib entomologischer Sammlungen der Welt bis 1960. Teil I: A bis K und Teil II L bis Z. Akademie der Landwirtschaftswissenschaften der Deutschen Demokratischen Republik, Berlin.

Koepcke H.W. 1982. Erläuterung der Beobachtungs- und Sammler-Nummern zu den in den Jahren 1949 bis 1974 in Peru durchgeführten biologischen Studien von Hans-Wilhelm Koepcke und Maria Koepcke. Hamburg. Availabe from https://issuu.com/ifrankej/docs/koepcke_h_w_1982_erl_uterung [accessed 5 Feb. 2021].

Lamas G. 1976. A gazetteer of Peruvian entomological stations (based on Lepidoptera). Revista Peruana de Entomología 19 (1): 17-25.

Available from https://www.revperuentomol.com.pe/index.php/rev-peru-entomol/article/view/621/596 [accessed 5 Feb. 2021].

Lamas G. 1980. Historia de la entomología en el Perú. II. Periodo de los viajeros, colectores y estudiosos especializados. Revista Peruana de Entomología 23 (1): 25-31. Available from https://www.revperuentomol.com.pe/index.php/rev-peru-entomol/article/view/710/684 [accessed 5 Feb. 2021].

Lucas R. 1920. Catalogus alphabeticus generum et subgenerum Coleopterorum orbis terrarum totius (famil., trib., subtr., sect. incl.). Pars I. Archiv für Naturgeschichte (A) 84 (1-5): i-xxxi, 1-696. Available from https://www.zobodat.at/pdf/Archiv-Naturgeschichte_84A_1_0001-0128.pdf [accessed 5 Feb. 2021].

Mierzwa-Szymkowiak D. \& Breure A.S.H. 2017. Inside and outside the Neotropics: three Polish naturalists during the late nineteenth and early twentieth centuries. Archives of Natural History 44 (1): 151-158. https://doi.org/10.3366/anh.2017.0423 
MINAM [Ministerio del Ambiente del Perú]. 2019. Mapa nacional de ecosistemas del Perú. Available from mapa-nacional-de-ecosistemas-del-peru [accessed 3 Jun. 2020].

Mlíkovský J. 2009. Types of birds in the collections of the Museum and Institute of Zoology, Polish Academy of Sciences, Warszawa, Poland. Part 3: South American birds. Journal of the National Museum (Prague), Natural History Series 178 (5): 17-180. Available from https://publikace.nm.cz/en/file/6a5c9f94784eaa047577335ba8553b02/16385/178-2009-05-Mlikovsky.pdf [accessed 5 Feb. 2021].

Morrone J.J. 2014. Biogeographical regionalisation of the Neotropical region. Zootaxa 3782 (1): 1-110. https://doi.org/10.11646/zootaxa.3782.1.1

Olson D.M., Dinerstein E., Wikramanayake E.D., Burgess N.D., Powell G.V., Underwood E.C., D’Amico J., Itoua I., Strand H.E., Morrison J.C., Loucks C.J., Allnutt T.F., Ricketts T.H., Kura Y., Lamoreux J.F., Wettengel W.W., Hedaeo P. \& Kassen K.R. 2001. Terrestrial ecoregions of the world: a new map of life on earth: a new global map of terrestrial ecoregions provides an innovative tool for conserving biodiversity. BioScience 51 (11): 933-938.

https://doi.org/10.1641/0006-3568(2001)051[0933:TEOTWA]2.0.CO;2

QGIS Development Team 2020. QGIS Geographic Information System. Open Source Geospatial Foundation Project. Available from http://qgis.osgeo.org [accessed 13 May 2020].

Ramírez-Salamanca J.M., Silva-Tavera D.F. \& Chani-Posse M.R. 2020. Systematic revision and phylogenetic assessment of two new Neotropical genera of the rove-beetle subtribe Philonthina (Coleoptera: Staphylinidae): Inesius gen. nov. and Rhaegalius gen. nov. Zoologischer Anzeiger 288: 151-167. https://doi.org/10.1016/j.jcz.2020.07.001

Roewer C.F. 1957. Arachnida Arthrogastra aus Peru, III. Senckenbergiana biologica 38 (1): 67-94.

Smetana A. 1995. Rove beetles of the subtribe Philonthina of America north of Mexico (Coleoptera: Staphylinidae): classification, phylogeny and taxonomic revision. Memoirs on Entomology, International 3: 1-946.

Solsky S. 1875. Matériaux pour l'entomographie de l'Amérique du Sud. Staphylinides recueillis par MM. C. Jelsky et le Baron de Nolcken dans le Pérou et la Nouvelle Grenade. Article III. Horae Societatis Entomologicae Rossicae 11 (1): 3-26.

Stephens L. \& Traylor M.A. 1983. Ornithological Gazetteer of Peru. Bird Department, Museum of Comparative Zoology, Harvard University, Cambridge, Massachusetts.

https://doi.org/10.5962/bhl.title.14634

Taczanowski L. 1874. Description des oiseaux nouveaux du Pérou central. Proceedings of the Scientific Meetings of the Zoological Society of London 1874 (1): 129-140.

https://doi.org/10.1111/j.1096-3642.1874.tb02461.x

Taczanowski L. 1875. Liste des oiseaux recueillis par M. Constantin Jelski dans la partie centrale du Pérou occidental. Proceedings of the Scientific Meetings of the Zoological Society of London 1874 (3): 501-565. https://doi.org/10.1111/j.1096-3642.1874.tb02510.x

Taczanowski L. 1884. Notice sur les localités du Pérou central explorées par M. Jelski. In: Taczanowski L. (ed.) Ornithologie du Pérou. Vol. I: 70-73. Typographie Oberthür, Rennes.

https://doi.org/10.5962/bhl.title.14183

Valencia N. 1990. Ecology of the Forests on the Western Slopes of the Peruvian Andes. PhD thesis, University of Aberdeen, Aberdeen.

Available from https://abdn.alma.exlibrisgroup.com/view/delivery/44ABE_INST/12152267510005941 [accessed 5 Feb. 2021]. 
Vaurie O. 1972. An ornithological gazetteer of Peru (based on information compiled by J.T. Zimmer). American Museum Novitates 2491: 1-36. Available from http://hdl.handle.net/2246/2699 [accessed 28 Jan. 2021].

Willink A. 1999. Biografías lilloanas. Revista de la Sociedad Entomológica Argentina 58 (3-4): 3-10. Available from https://www.biotaxa.org/RSEA/article/view/32472/28865 [accessed 5 Feb. 2021].

Manuscript received: 15 July 2020

Manuscript accepted: 27 November 2020

Published on: 16 February2021

Topic editor: Nesrine Akkari

Section editor: Max Barclay

Desk editor: Pepe Fernández

Printed versions of all papers are also deposited in the libraries of the institutes that are members of the EJT consortium: Muséum national d'histoire naturelle, Paris, France; Meise Botanic Garden, Belgium; Royal Museum for Central Africa, Tervuren, Belgium; Royal Belgian Institute of Natural Sciences, Brussels, Belgium; Natural History Museum of Denmark, Copenhagen, Denmark; Naturalis Biodiversity Center, Leiden, the Netherlands; Museo Nacional de Ciencias Naturales-CSIC, Madrid, Spain; Real Jardín Botánico de Madrid CSIC, Spain; Zoological Research Museum Alexander Koenig, Bonn, Germany; National Museum, Prague, Czech Republic.

\section{Supplementary material:}

Supp. file 1. Table 1. List of potential localities georeferenced in Junín Department where Jelski probably collected the holotype of Ophionthus serpentinus Bernhauer, 1908 in 1873, based on the information available on the holotype labels. https://doi.org/10.5852/ejt.2021.735.1237.3597

Supp. file 2. Morphological matrix after Chani-Posse \& Ramírez-Salamanca (2020a), including the two species of Ophionthus Bernhauer, 1908. https://doi.org/10.5852/ejt.2021.735.1237.3599 